\title{
Wzornictwo UTP - dydaktyka utylitarna. Doświadczenia i szanse dla miasta i biznesu
}

\section{UTP design - utilitarian didacticism. Experiences and opportunities for the city and business}

\begin{abstract}
Streszczenie
Kreatywność studentów Wzornictwa znajduje ujście w realizacjach dedykowanych przestrzeni publicznej, których zakres i zasięg monitoruje Rada do Spraw Estetyki przy Prezydencie Miasta. Współpraca określona w umowie zawartej między miastem a uczelnią dała początek nowej formule studiów, zainicjowała nowe kontakty i zamówienia. Praktyki, staże, praca w firmach to wartość dodana dla absolwentów. Utylitarna dydaktyka wychodzi naprzeciw inteligentnej trójstronnej współpracy.
\end{abstract}

Słowa kluczowe: Wzornictwo, Bydgoszcz, UTP, Rada do Spraw Estetyki

Abstract

In last three years, Bydgoszcz has opened itself on the University's potential. Creativity of students of University of Technology and Life Sciences finds its release in executions dedicated to the city space, of which range and extent is being monitored by Civic Aesthetics Council by the City President. Cooperation, declared in the agreement between the City and the University, has given a rise to a new formula of studies, initiated new contacts and assignments. Apprenticeships, internships, careers in companies is an extra value for the graduates. Utilitarian didacticism accommodates intelligent tripartite cooperation.

Keywords: Design, Bydgoszcz, UTP, Civic Aesthetics Council 


\section{1. „ARTYSTYCZNY” KIERUNEK NA „ŚCISŁEJ” UCZELNI}

Mija 10 lat, odkąd na Uniwersytecie Technologiczno-Przyrodniczym w Bydgoszczy kształcącym studentów na kierunkach ścisłych, technicznych i rolniczych, w ramach Wydziału Inżynierii Mechanicznej rozpoczął działalność Zakład Wzornictwa ${ }^{1}$. Idea stworzenia kierunku studiów Wzornictwo w strukturze wydziału o tak silnie zdefiniowanym inżynierskim profilu okazała się, jak pokazały kolejne lata, strzałem w dziesiątkę. Połączenie artystycznego, kreatywnego warsztatu z wiedzą techniczną, dostępem do technologii, praktyczną możliwością weryfikowania projektów, wreszcie dodatkowa baza przedmiotów technicznych, z jakimi muszą się zmierzyć studiujący w Bydgoszczy przyszli designerzy - to wszystko pozwoliło myśleć o praktycznym wykorzystaniu potencjału tego kierunku². Autorka prowadzi pracownię Kształtowania Przestrzeni na kierunku Wzornictwo, dlatego skupi się w swojej prezentacji na współpracy uczelni, miasta i biznesu w zakresie działań w przestrzeni publicznej.

Kształcenie przyszłych projektantów w oparciu o praktyczne wykorzystanie nabywanych podczas studiów umiejętności stało się warunkiem sine qua non. Przyjęto założenie, że student tylko w realnych warunkach zdoła poznać zarówno wszystkie oczekiwania, jak i ograniczenia, które wiążą się z realizacją zadania projektowego. Pierwszym zadaniem projektowym, z którym przyszło się zmierzyć młodym designerom, była koncepcja płyty Starego Rynku w Bydgoszczy. Bardzo trudny, wręcz kontrowersyjny temat obarczony długą historią. Przestrzeń rynku pozbawiona pierzei zachodniej, ze zburzonym kościołem jezuitów, okaleczona zarówno przez hitlerowców, jak i później przez komunistyczne „zdobnictwo", była tematem wielu dyskusji, opracowań i konkursów architektonicznych ${ }^{3}$. Do dziś nie podjęto ostatecznej decyzji co do wyglądu rynku i losów pierzei. Ważne jednak było, by dać młodym ludziom możliwość w miarę swobodnego wypowiedzenia się na temat tego miejsca, uwzględniającego również oczekiwania użytkowników przestrzeni. Tu skorzystano z doświadczeń think tank Project for Public Spaces ${ }^{4}$.Uwzględnienie aspektu społecznego stało się dodatkowym walorem powstających opracowań. Świadomość odbioru przestrzeni przez jej użytkowników, projektowanie behawioralne ${ }^{5}$ znalazła tu po raz pierwszy swoje zastosowanie.

Projekty studenckie zostały zaprezentowane na spotkaniu z udziałem Prezydenta Miasta oraz wielu decyzyjnych urzędników. Podkreślono świeżość spojrzenia młodych ludzi, a jednocześnie chęć stworzenia miejsca przyjaznego, żyjącego, akceptowanego, a nie jedynie prawidłowo zaprojektowanego. Naturalną pokusą dla urzędników była możliwość bezpłatnego skorzystania z potencjału młodych głów. Dla studentów - pozytywny odbiór ich pracy stał się dodatkowym (oprócz zaliczenia semestru) bodźcem aktywizującym. Temat Rynku zakończył się nagrodami ufundowanymi przez Prezydenta Miasta oraz zaproponowaniem odbycia praktyk w profesjonalnym biurze projektowym.

Te walory sporządzonych koncepcji stały się bezpośrednim powodem do podjęcia ściślejszej współpracy w miastem. 
24 kwietnia 2014 roku nastąpiło podpisanie Listu Intencyjnego między Urzędem Miasta Bydgoszczy a Zakładem Wzornictwa, który zapoczątkował bardziej systemowe kontakty. Wydaje się dziwne, że dopiero po siedmiu latach istnienia kierunku Wzornictwo nawiązano taką współpracę. Trzeba jednak dodać, że zaistnienie w świadomości urzędników, a następnie firm i wszelkich podmiotów stanowiących potencjalnych partnerów jest procesem, który trwa, któremu nie sprzyja kojarzenie Wzornictwa z uczelnią inną niż artystyczna. Należało podkreślać walor technicznego „osadzenia” kierunku.

\section{WSPÓŁPRACA Z MIASTEM}

25 czerwca 2013 roku odbyło się pierwsze spotkanie Rady do Spraw Estetyki Bydgoszczy powołanej przez Prezydenta Miasta ${ }^{6}$. Ciało pracujące jest całkowicie społeczne, w jego skład wchodzą osoby różnych profesji - architekci, konserwatorzy zabytków, historycy sztuki, plastycy i społecznicy. Zadaniem Rady jest kreowanie i poprawianie estetyki miasta. Rada bardzo szybko nawiązała kontakt z Zakładem Wzornictwa, widząc niemałe możliwości włączenia studentów do przygotowywania opracowań projektowych dla Bydgoszczy. Autorka jest również członkiem Rady - można więc było mieć ścisły kontakt i na bieżąco określać zakres działań. Jedną z pierwszych korzyści wynikających z tych kontaktów jest odbywanie przez studentów Wzornictwa stażów w Biurze Plastyka Miejskiego.

Plastyk miejski przy wsparciu Rady zainicjował ideę zaprojektowana wzoru bydgoskiej ławki miejskiej, a zadanie zostało przekierowane na Zakład Wzornictwa. Efektem pracy było 47 projektów designerskich ławek miejskich dedykowanych różnym lokalizacjom, dla różnych kontekstów. Propozycje studentów zostały przedstawione do oceny Rady, która nagrodziła 3 najlepsze. Na publiczną prezentację projektów, która odbyła się w Galerii Miejskiej BWA z udziałem Prezydenta Miasta, zaproszono przedstawicieli lokalnego biznesu. Zgłoszono pierwsze deklaracje sfinansowania wykonania nagrodzonych obiektów. Pierwszą ławkę ustawiono przy budynku opery, jej realizację w 2016 roku zawdzięczamy Fundacji Take Care? W tym samym roku na bydgoskiej Wyspie Młyńskiej została „odsłonięta” kolejna designerska ławka - tym razem sfinansowana przez jedną z firm ubezpieczeniowych. Trzeba zwrócić uwagę na fakt, że te jednostkowe działania miały niemałe znaczenie promocyjne. Bydgoskie Wzornictwo zaczęło coraz bardziej „wrastać” w świadomość lokalnych przedsiębiorców. Aktualnie jest realizowany kolejny nagrodzony przez Radę projekt- tym razem ławka stanie się wiatą przystankową w prestiżowej lokalizacji przy Placu Teatralnym. Sponsorem zaś będzie firma Tyco Electronics.

Z inicjatywy Rady do Spraw Estetyki studenci Wzornictwa opracowali kilka koncepcji zagospodarowania Placu Kościeleckich, skupiając się oczywiście w głównej mierze na meblach miejskich. Projekty zostaną wykorzystane w opracowaniu dokumentacji technicznej, a autorzy będą włączeni do wybranej pracowni projektowej. 
Podobnie stało się z innymi zadaniami, które w ramach przedmiotu kształtowanie przestrzeni - były realizowane przez studentów Wzornictwa. Kolejno - elewacja tzw. Galeriowca, dojazdy na Wyspę Młyńską, aranżacja ulicy Długiej i Zaułek, projekty kiosku bydgoskiego, mobilnych straganów, info-punktów, a nawet bydgoska księga standardów wzorów - to tylko niektóre tematy realizowane jako zadania semestralne, które mają bezpośrednie przełożenie na ich realizację. Koordynatorem jest tu bez wątpienia miejski plastyk, który często jako pierwszy informuje zainteresowane podmioty o posiadanych projektach i możliwościach ich wykorzystania ${ }^{8}$.Ścisła współpraca z Radą do Spraw Estetyki daje studentom Wzornictwa szerokie możliwości dostępu do tematów projektowych będących w gestii Miasta. Studenci, przygotowując projekty dedykowane określonej przestrzeni, zyskują podwójnie - z większym zaangażowaniem podchodzą do swych zadań - zdając sobie sprawę z tego, że nie tylko się uczą, ale i mogą uczestniczyć w kolejnych etapach realizacyjnych, czasem także wiążąc się już zawodowo z firmami realizującymi ich pomysły. Istotnym pozostaje fakt posiadania przez kierunek Wzornictwo technicznego zaplecza, wynikającego z przynależności do Wydziału Inżynierii Mechanicznej. Studenckie projekty są także weryfikowane pod kątem możliwości ich wykonania, kwestii wytrzymałościowych, konstrukcyjnych, technologicznych, nierzadko korzysta się z prototypowania. Rozbudowane zaplecze maszynowe daje takie możliwości.

\section{PROJEKTY DLA STAREGO FORDONU}

Stary Fordon to obecnie dzielnica Bydgoszczy, a pierwotnie samodzielne miasteczko przyłączone w 1973 roku do Bydgoszczy dla pozyskania przestrzeni pod budownictwo mieszkaniowe jak również budowę obecnego Uniwersytetu (dawniej Akademia Techniczno-Rolnicza) ${ }^{9}$. Pozostałe po dawnym, niewiele młodszym od Bydgoszczy miasteczku: zabudowa stanowiąca przykład ciekawej małomiasteczkowej architektury z zachowaną synagogą, kościołem ewangelickim, katolickim, sąsiadująca z nią Wisła - stały się w ostatnim czasie tematem zainteresowania gospodarzy Miasta, również za sprawą programów rewitalizacji oraz dzięki ogromnej aktywności lokalnej społeczności.

W porozumieniu ze Stowarzyszeniem Miłośników Starego Fordonu wybrano dwie lokalizacje wymagające najpilniejszej interwencji i studenci Wzornictwa rozpoczęli etap opracowywania koncepcji zagospodarowania Rynku oraz tzw. Hafy, czyli storofordońskiego portu. Założeniem prowadzącego zadanie semestralne było nie tylko wprowadzenie studentów w kolejną istniejącą przestrzeń i zmierzenie się z oczekiwaniami użytkowników, ale również w ślad za tym - możliwość realizacji w szerszym niż dotąd zakresie. Pierwotny udział miasta polegał na wsparciu ze strony Miejskiej Pracowni Urbanistycznej, udostępnieniu mapy 3D i wszelkich niezbędnych materiałów wyjściowych. SMSF w kolei stanowiło głos mieszkańców, a więc użytkowników przestrzeni, którzy na podstawie wcześniejszych wywiadów dokładnie potrafili określić swoje oczekiwania. 
Powstało 8 projektów - 4 dla rynku i 4 dla portu. Były one najpierw pokazywane na spotkaniu z mieszkańcami Starego Fordonu ${ }^{10}$ - tam studenci sami opowiadali o założeniach projektowych, wskazywali najważniejsze cechy i atuty swoich pomysłów, ćwicząc przy okazji tak ważną umiejętność publicznej prezentacji. Projekty spotkały się z dużym zainteresowaniem i akceptacją, stąd kolejna prezentacja nastąpiła już w Urzędzie Miasta, gdzie autorzy projektów omówili ich zawartość przed Prezydentem i Wiceprezydentem Miasta odpowiedzialnym za rewitalizację. Obecni byli również przedstawiciele SMSF. Na spotkaniu zapadła decyzja by Miasto ogłosiło przetarg na wybór pracowni projektowej, która wykona część techniczną w oparciu o zakres określony wspólnie ze stowarzyszeniem i autorami wybranych przez mieszkańców najlepszych projektów. Ich autorzy ze wszystkimi konsekwencjami formalnymi wejdą w skład zespołu opracowującego projekt techniczny. Wybór i przystąpienie do opracowania nastąpi do końca 2017.

\section{DALSZY ROZWÓJ}

Aktywność studentów Wzornictwa i ich zmierzanie się z konkretnymi zadaniami projektowymi, których skala rośnie, a możliwości realizacji również są coraz większe - stały się przyczynkiem do rozważań na temat powiązania formalnego tej aktywności z interesami Uczelni. UTP posiada co prawda jednostkę wyspecjalizowaną w prowadzeniu zewnętrznych projektów, ale są one dedykowane konkretnym projektom najczęściej zlecanym w ramach programów unijnych, marszałkowskich, wspieranych grantami, międzywydziałowych, a więc takich, których skala jest zupełnie inna ${ }^{11}$. Okazało się jednak, że sytuacja pojedynczego autora, jednocześnie twórcy, działającego przy wsparciu Uczelni - nie jest rozwiązana. Wynika to także z technicznego charakteru uczelni.

Obecnie opracowywane są założenia, które określą wewnętrzne zasady udziału w prawach autorskich i wynikających z nich zysków. Uczelnia zabezpiecza interesy autorów projektów, prowadzi procedury patentowe i zastrzegające wzory, sama gwarantując udziały w ewentualnych zyskach w określonych w umowie proporcjach.

Potencjał studentów Wzornictwa jest dostrzegany przez inne firmy, które organizują dla nich konkursy, często gwarantując realizację - np: Loft Decora - producent mebli, Optiguard - producent standów, Folkstar i inne. Kilkuletnią tradycję ma współpraca z bydgoską PESĄ - która najzdolniejszym studentom organizuje staże, nagradza najlepsze dyplomy i zatrudnia absolwentów.

Dotychczasowe doświadczenia i rosnące zainteresowanie potencjałem studentów pozwoliło myśleć o przekształceniu studiów w dualne - z wyraźnym rozgraniczeniem między zajęciami teoretycznymi, a praktycznymi. Pierwszym jednak krokiem była zmiana w 2016 roku studiów licencjackich na inżynierskie i jeszcze większe wzmocnienie bloku przedmiotów technicznych. Od 2017 roku sukcesywnie zwiększa się liczbę godzin „praktycznych” dla studentów Wzornictwa, a od 2018 dualność studiów będzie już faktem. Organizacja takich studiów wymaga naturalnie przygotowania zaplecza w postaci właściwych zakładów i firm, które zechcą związać się z uczelnią. Jednym z podmiotów będzie PESA, a także Bydgoska 
Fabryka Mebli. Prowadzone są rozmowy z agencjami reklamowymi, a także firmami zajmującymi się produkcją z tworzyw sztucznych - to wiodące branże na bydgoskim rynku. Będzie to pierwszy tego typu kierunek studiów w Bydgoszczy.

Współpraca z miastem i z przemysłem to proces - budowanie świadomości potencjalnych odbiorców, szukanie możliwości pokazania swych dokonań i umiejętności, przy jednoczesnym rozwijaniu zaplecza technicznego i poszerzaniu własnego potencjału.

3 marca 2017 roku odbyła się na UTP pierwsza duża prezentacja studenckich projektów i realizacji skierowanych dla przestrzeni miasta i wszelkich podmiotów zewnętrznych pod nazwą Young4Design ${ }^{12}$. Udział wzięli w niej zarówno przedstawiciele firm, producentów, urzędów, jak i organizacji pracodawców. Wykładowcy zapoznali gości z dotychczasowymi dokonaniami studentów, a także świeżych absolwentów Wzornictwa. Również oni sami pokazali swoje najnowsze projekty, które zostały wybrane do realizacji.

Young4Design w założeniu ma stać się cykliczną imprezą targowo-konferencyjną, w ramach której będzie się szukać i łączyć projektantów z producentami. Stworzenie platformy do współpracy wydaje się na obecnym etapie wręcz niezbędne.

18 kwietnia 2017 roku w Bydgoszczy podczas ogólnopolskich obchodów Międzynarodowego Dnia Ochrony Zabytków spotkali się przedstawiciele rządu, samorządów i środowisk konserwatorskich. Zwrócono uwagę na znaczenie Ustawy Krajobrazowej i lokalne możliwości jej realizacji. Szczególnie mocno podkreślano konieczność reinterpretacji często zdegradowanych przestrzeni przy użyciu świadomie dobieranych narzędzi min. mebli miejskich, elementów dekoracyjnych, grafiki materiałów ${ }^{13}$. Bardzo dobitnie podkreślono doświadczenia i znaczenie Rady do Spraw Estetyki i współpracę Miasta z Uniwersytetem Technologiczno-Przyrodniczym, a w szczególności z Wzornictwem.

\section{PODSUMOWANIE}

Tak od pierwszych tematów koncepcyjnych dotyczących przestrzeni Bydgoszczy udało się przejść do programowej współpracy opartej o ścisły kontakt z Radą do Spraw Estetyki, realizacji konkretnych projektów, modyfikowania profilu studiów, wreszcie zbudowania platformy kontaktowej, jaką jest Young4Design.

Wyższa uczelnia techniczna, której pozycja nie bazuje na tradycji, prestiżu i ogromnym dorobku naukowym, może szukać swojej szansy rozwoju w oparciu o lokalny biznes i współpracę z Miastem; z pożytkiem dla wszystkich stron.

Konsekwencja w działaniu i wyraźnie określony kierunek w połączeniu z założeniem, że na efekty trzeba poczekać, wypracowując je na początku w oparciu o aktywność, która nie od razu przyniesie materialne korzyści - to pierwszy etap procesu zmierzającego do zbudowania synergicznego związku podmiotów. Utylitarna dydaktyka stanowi ważne narzędzie w budowaniu coraz silniejszych powiązań pomiędzy uczelnią, miastem i biznesem. 


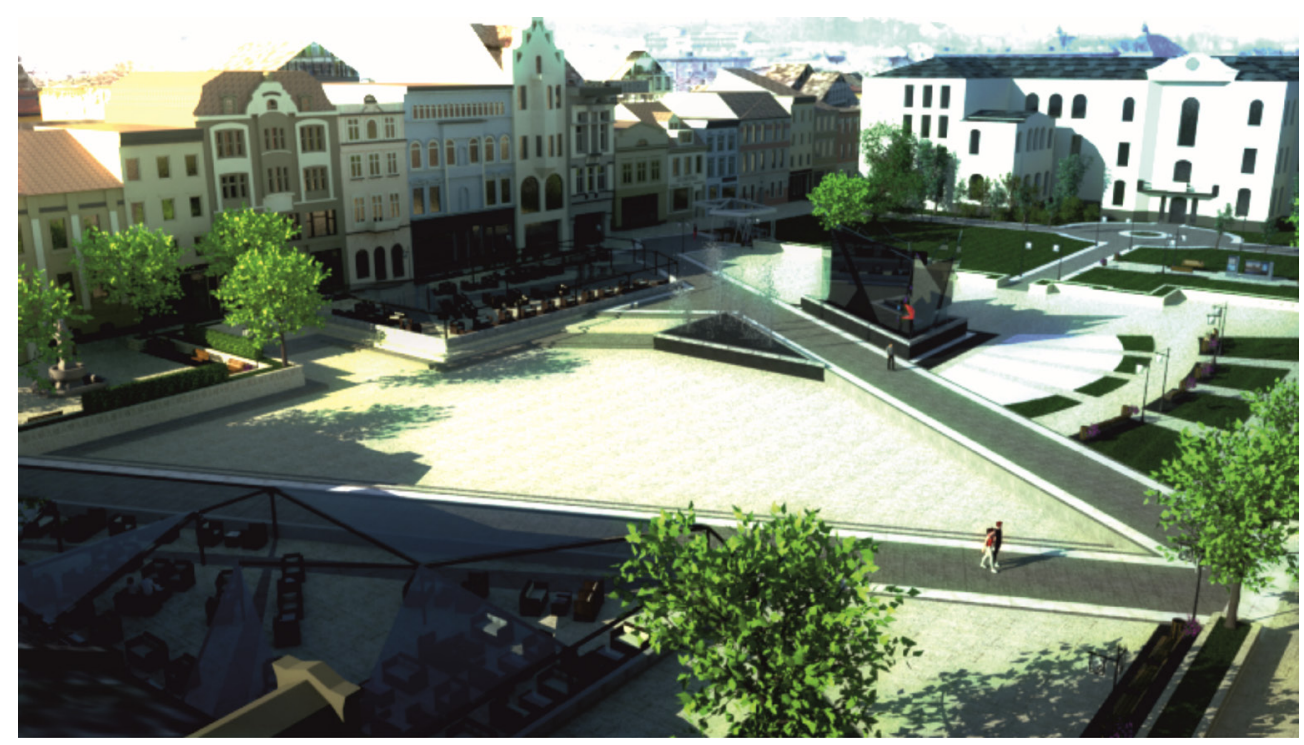

II. 1. A. Bożek, K. Kulik, Projekt płyty Starego Rynku (materiały autorki) III. 1. A. Bożek, K. Kulik, Stary Rynek's plate design

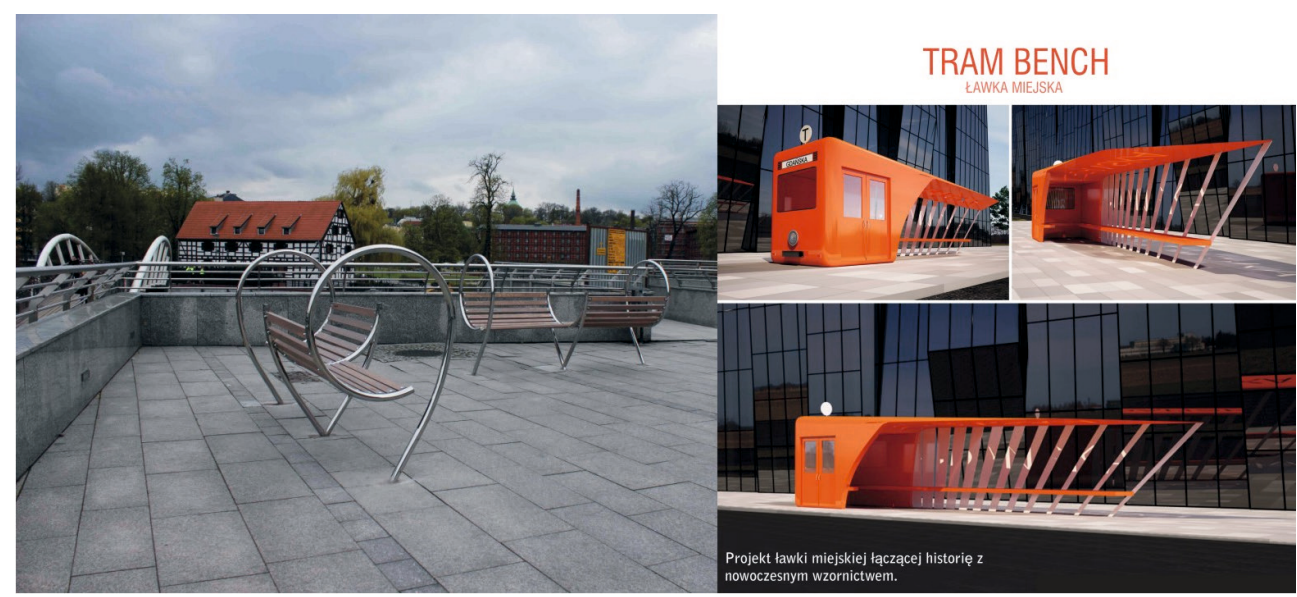

II. 2. Ring, proj. A. Cichosz (realizacja 2016), Tram Bench, proj. M. Walczak, w trakcie realizacji, (materiały autorki)

III. 2. Ring, proj. A. Cichosz (produced in 2016), Tram Bench, proj. M. Walczak, work in progress 


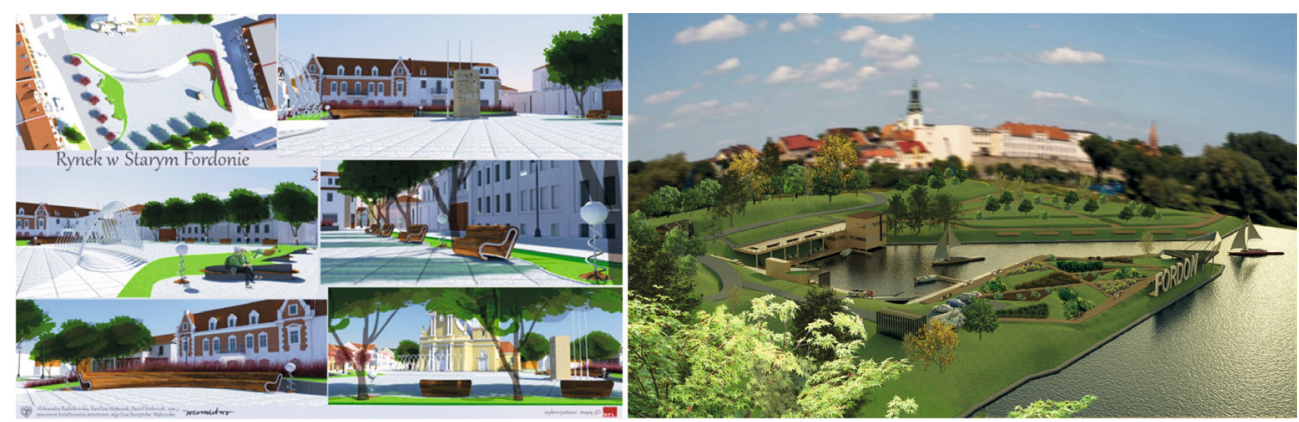

II. 3. Stary Fordon - projekty studenckie 2016 (materiały autorki)

III. 3. Stary Fordon - student's projects 2016
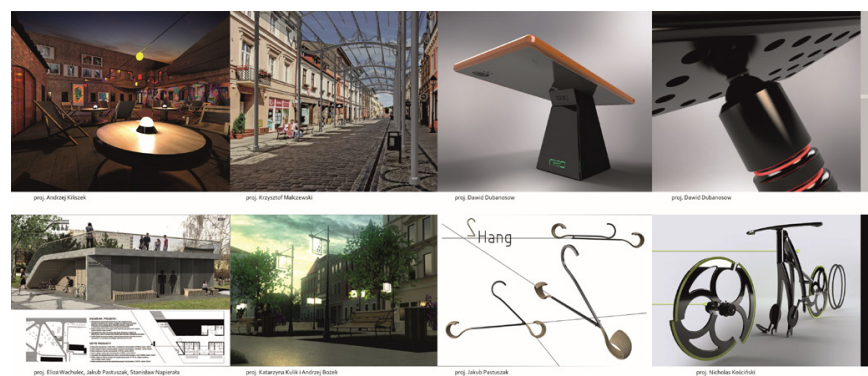

\section{Young 4Design}
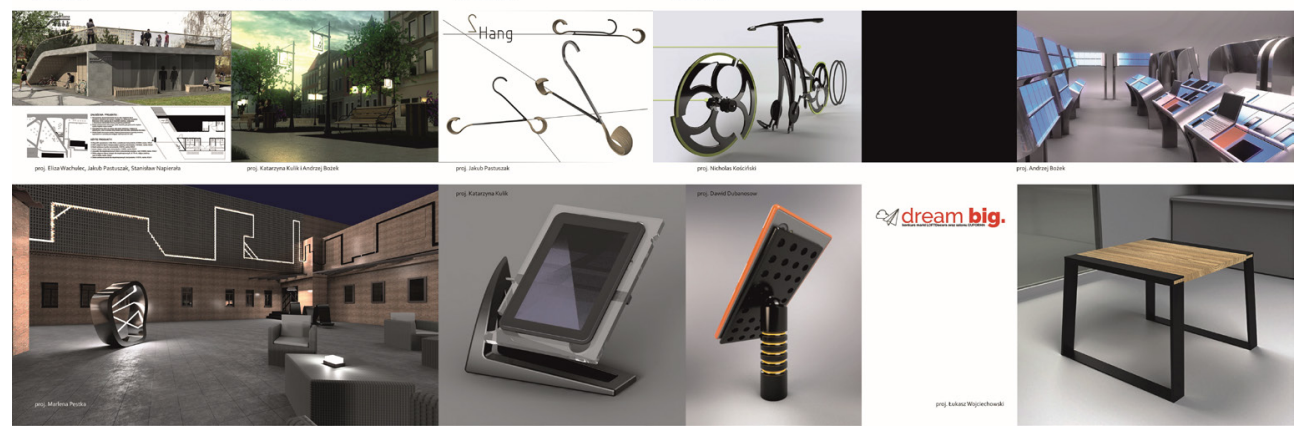

II. 4. Katalog Young4Design 2017 - fragment (materiały autorki)

III. 4. Katalog Young4Design 2017 - part 


\section{PRZYPISY}

${ }^{1}$ http://www.expressbydgoski.pl/archiwum/a/beda-uczyc-ich-dobrych-wzorow,11339677 (dostęp: 20.04.2017).

2 Zakład Wzornictwa UTP, http://wzornictwo.utp.edu.pl/ (dostęp: 03.04.2017).

3 S. Pastuszewski, Świątynia-wotum, Instytut Wydawniczy „Świadectwo”, Bydgoszcz 1990.

4 Jak przetworzyć miejsce, podręcznik kreowania udanych przestrzeni publicznych, http:// www.mck.pk.edu.pl/panel/dokumenty/PPS,\%20Jak_przetworzyc_miejsce.pdf (dostęp: 20.04.2017).

5 A. Bańka, Architektura psychologicznej przestrzeni miasta. Behawioralne Podstawy Projektowania, SPiA, Poznań 2016.

6 Zarządzenie 583/2013 z dnia 4 października 2013, http://www.bip.um.bydgoszcz.pl/binary/584-2013_tcm30-154955.pdf (dostęp: 20.04.2017).

7 http://bydgoszcz.wyborcza.pl/bydgoszcz/1,48722,16628075,Niezwykly_projekt_Studenci_stworzyli_47_kultowych.html (dostęp: 20.04.2017).

8 http://magazyn.7dni.pl/321393,Wzor-na-miasto-w-ktorym-chce-sie-zyc.html (dostęp: 20.04.2017).

9 Z. Biegański (red.), Dzieje Fordonu i okolic, Wyd. Kujawsko-Pomorskie Wydawnictwo Kulturalne, Bydgoszcz 1997.

${ }^{10}$ http://bydgoszcz.wyborcza.pl/bydgoszcz/7,48722,21432387,zaprojektowali-port-i-rynek-studenckie-pomysly-na-fordon.html (dostęp: 21.04.2017).

${ }^{11}$ Centrum Transferu Technologii UTP, http://www.utp.edu.pl/pl/rci-centrum-transferu-technologii (dostęp: 21.04.2017).

12 http://www.bydgoszcz.pl/aktualnosci/tresc/studenci-pokazali-projekty-na-young4design (dostęp: 21.04.2017).

13 http://bydgoszcz.wyborcza.pl/bydgoszcz/7,48722,21659793,estetyka-miast-wielka-debata-w-bydgoszczy.html (dostęp: 21.04.2017).

\section{BIBLIOGRAFIA}

Bańka A., Architektura psychologicznej przestrzeni miasta. Behawioralne Podstawy Projektowania, SPiA, Poznań 2016.

Biegański Z. (red.), Dzieje Fordonu i okolic, Wyd. Kujawsko-Pomorskie Wydawnictwo Kulturalne, Bydgoszcz 1997.

Bydgoszcz, http://www.bydgoszcz.pl/aktualnosci/tresc/studenci-pokazali-projekty-na-young4design (dostęp: 21.04.2017).

Centrum Transferu Technologii UTP, http://www.utp.edu.pl/pl/rci-centrum-transferu-technologii (dostęp: 21.04.2017). 
Express Bydgoski, http://www.expressbydgoski.pl/archiwum/a/beda-uczyc-ich-dobrych-wzorow,11339677 (dostęp: 20.04.2017).

http://bydgoszcz.wyborcza.pl/bydgoszcz/1,48722,16628075,Niezwykly_projekt_Studenci_stworzyli_47_kultowych.html (dostęp: 20.04.2017).

http://bydgoszcz.wyborcza.pl/bydgoszcz/7,48722,21432387,zaprojektowali-port-i-rynek-studenckie-pomysly-na-fordon.html (dostęp: 21.04.2017).

http://bydgoszcz.wyborcza.pl/bydgoszcz/7,48722,21659793,estetyka-miast-wielka-debata-w-bydgoszczy.html (dostęp: 21.04.2017).

Jak przetworzyć miejsce, podręcznik kreowania udanych przestrzeni publicznych, http:// www.mck.pk.edu.pl/panel/dokumenty/PPS,\%20Jak_przetworzyc_miejsce.pdf (dostęp: 20.04.2017).

Magazyn, http://magazyn.7dni.pl/321393,Wzor-na-miasto-w-ktorym-chce-sie-zyc.html (dostęp: 20.04.2017).

Pastuszewski S., Świątynia-wotum, Instytut Wydawniczy „Świadectwo”, Bydgoszcz 1990.

Pluta K., Przestrzenie publiczne miast europejskich, projektowanie urbanistyczne, Oficyna Wydawnicza Politechniki Warszawskiej, Warszawa 2012.

Zakład Wzornictwa UTP, http://wzornictwo.utp.edu.pl/ (dostęp: 03.04.2017).

Zarządzenie 583/2013 z dnia 4 października 2013, http://www.bip.um.bydgoszcz.pl/binary/584-2013_tcm30-154955.pdf (dostęp: 20.04.2017). 